benefit derived from the bandage, or laced stocking, by affording lateral pressure, rather leads to this conclusion. The atmospheric pressure here wants the opposing pressure before alluded to. Take, again, the circulation of the brain : there, muscular action and atmospheric pressure are absent; they cannot assist the blood to the sinuses. But, admitted the lateral pressure of the distending arteries-admit the resistance offered by the bony covering of the skull in lieu of that of the atmosphere, and the phenomenon is solved. Jammed up between the distending arteries, and the unyielding calvarium, the contents of the veins are forced into the sinuses, and thence to the jugulars, and home.

That the brain would alter its figure if it could, is evidenced by the bulging of the dura mater through an opening made by the trephine. That the same pressure is made though the opening be not there, no one will deny; but not being there, it exerts its influence on the yielding contents of the skulinamely, the veins. Take, again, the imperfect closure of the bones of the head in infancy: if the sutures of the skull are very opeñ, the chances of the child arriving at maturity are much lessened. And why is this? Simply becauce the resistance opposed to the action of the heart by the yielding membranous covering is not sufficient to secure that lateral pressure necessary to the emprying of the venous circulation, and congestion and effusion are the consequences.

What the calvarium is to the veins of the hrain, the atmo spheric pressure is to the veins of the rest of the body. They afford a resistance to the lateral pressure occasioned by the expansion of the arteries, and thus enable it, in my opinion, greatly to assist the venous circulation.

It is not necessary to adduce further examples; that would require more space than $I$ could ask in your publication. Enough has been said to show my views. Besides, it may be that my premises may be satisfactorily npset; if so, enough has been said already. It may be, also, that all this has been advanced before, and received its quietus before $I$ received $m y$ existence. It may be, however, that my views may be favourably received; if so, I shall have ample opportunities, shonld I feel so disposed, to place them before the profession in a more comprehensive form.

I am, Sir, your most obedient servant,

Savile-row, Sept. 1859.

JAMES NIOHOLS, F.R.C.S.

\section{THE SMETHURST CASE.}

(NOTE FROM DR. JULIUS AND MR. BIRD.)

\section{To the Editor of THE LANCET.}

SrR,-In a letter from Dr. Girdwood, appearing in your impression of the 3rd of September, a statement is made, of so unjust and wholly unwarrantable a nature, that although we have hitherto avoided entering into any controversy on the subject of Dr. Smethurst's trial, we cannot allow it to pass without observation.

Dr. Girdwood states that " amongst the other acts of omission, as well as of commission, that are to be lamented as having occurred in the treatment of the case of Miss Bankes, one of much importance must not be unnoticed: it is, that during the life of the lady the urine was never analyzed. Neither to Dr. Julius nor to Mr. Bird, nor to Dr. Todd, nor, lastly, to Dr. Taylor, did the idea ever occur of examining this im portant secretion."

In reply to Dr. Girdwood's unfounded assertion, we now state that we both endeavoured to procure some urine, but the answer received from Dr. Smethurst was, that being passed with the motions, it was impossible to collect it separately. Dr. Todd and Dr. Taylor also urged upon us the importance of obtaining this secretion, but from the reason above stated we were unable to do so.

We refrain from making any further observation on the contents of Dr. Girdwood's letter, but must express our regret that any gentleman should have made so bold an assertion, involving the characters of four professional men, without the slightest foundation for his statements.

The insertion of the above would greatly oblige, $\mathrm{Sir}$, Your very obedient servants,

Richmond, Sept. 1859

Frederic G. Julius, S. Dougan Bird.
THE MEDICAL SERVICE OF THE ROYAL AND INDIAN ARMIES.

To the Editor of THE LANCET.

$\mathrm{S}_{I R,-I}-\mathrm{I}$ have just seen the number of THE LANCET for the 2nd of April, in which there is a long letter signed " An Assistant-Surgeon of the Royal Army." This gentleman compares the Royal and Indian medical services, appearing to be very much in favour of the latter. He concludes his letter thus: "But if there is to be found a service which offers something like remuneration-nay, even the prospect of ultimate affluence, in return for a lite of sad exile and toil, I believe that service to exist in the Indian forces."

Now, whatever object this gentleman had in view in praising so very highly the Indian medical service, I have no hesitation in saying a graver error was never made; nor should I trouble myself to reply to his rambling letter, but that $I$ wish my young medical brethren to be on their guard, and not be de. ceived by such writers. Enough that he is himself a proof to the contrary of what he states, by remaining in a service so. much inferior to one he has the opportunity of entering every half-year; but he is too wise-he knows he is far better off in. the Poyal service. He says we of the Indian service "are in the enjoyment of larger jncomes and more lucrative posts at a similar age to theirs." Here, again, I difer from him. I have just run over the Royal Army List, and of all the Royal regiments serving in India, there are only ten surgeons senior to. myself in the army, and all the rest junior-some many years junior; while I am an assistant-eurgeon of eighteen year's' service, (and if you take up the Madras Army List, you will find six or seven more equally fortunate.)

Now, Sir, though this "Royal Assistant,Surgeon" grumbles because he has no charge during the first few years of service, yet I will stake my existence that many of those Royal surgeons, my juniors, have drawn more pay from first to last than I have Look at the difference of pay between a surgeon of $a$ Royal regiment and that of a native infantry regiment: the former gets from $£ 100$ to $£ 110$ a month, while the latter only draws $£ 71$; so that it will not be difficult to comprehend that the difference of pay now more than compensates for the loss of charge as an assistant surgeon. But how long are they assistant-surgeons?--six or seven years; while I have been toiling on a bare pittance for eighteen years. There are surgeons in the Royal army who could not have commenced their studies when I enter d the service, and yet this is the service so lauded. My young friends, beware in time! The pension in the Royal service is better now than ours. And that brings me to the Warrants. Will you, Mr. Fiditor, have the goodness to place both side by side: not a word about pay in ours. I might go home on sick cerificate to-morrow, and what do you think my pay would be ?-6s.6d. perdiem; while an assistantsurgeon just entering the Rnyal army gets $10 s$. per diem. Look on this and that. The day is gone by for the Indian service. I do not deny that formerly it was the best service in the worldsic transit gloria mundi; but its sun has set since the Royal Warrant appeared; and unless there is a very great improvement made in the retiring pensions and pay while on leave to Europe, I fancy very few men will enter the Indian service while the Royal service is open to them. Promotion, too, has been getting slower every year; nor is there much chance of its improving. We are all too poor to retire. There are a few at the Presidency towns who draw good salaries, which many increase by private practice; but then how few these are? And these appointments are not always given for merit, as you fondly suppose at home. Oh, no; interest carries the day in India as elsewhere: it is not whether you are fitted for the appointment, but is the appointment fitted for you? I must now stop, or I shall be actually pointing to the parties, which I have no desire to do.

June, 1859. I am, Sir, yours faithfully, A Madras Assistant-Surgeon of Eighteen Years' Service.

\section{To the Editor of THE LANCET.}

SrR,-In corroboration of the monopoly alluded to by your correspondent, "An Assistant-Surgeon of the Royal Army," in his letters of the 19 th March and 2nd April, I would adduce the following instances, which, during a short Indian career, have come within my observation. I shall state these instances separately.

1. A vacancy occurred in a native corps. A Royal staff. surgeon, unemployed, familiar enough for colloquial purposes 297 